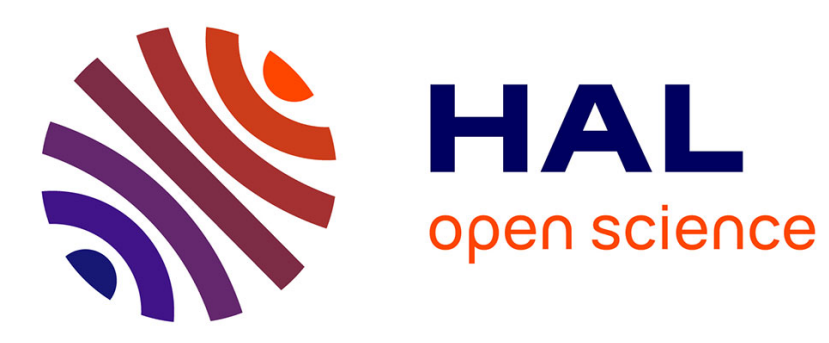

\title{
Characterization of solar fuels obtained from beech wood solar pyrolysis
}

Kuo Zeng, Daniel Gauthier, Doan Pham Minh, Elsa Weiss-Hortala, Ange Nzihou, Gilles Flamant

\section{To cite this version:}

Kuo Zeng, Daniel Gauthier, Doan Pham Minh, Elsa Weiss-Hortala, Ange Nzihou, et al.. Characterization of solar fuels obtained from beech wood solar pyrolysis. Fuel, 2017, 188, p. 285-293. 10.1016/j.fuel.2016.10.036 . hal-01619246

\section{HAL Id: hal-01619246 https://hal.science/hal-01619246}

Submitted on 4 May 2018

HAL is a multi-disciplinary open access archive for the deposit and dissemination of scientific research documents, whether they are published or not. The documents may come from teaching and research institutions in France or abroad, or from public or private research centers.
L'archive ouverte pluridisciplinaire HAL, est destinée au dépôt et à la diffusion de documents scientifiques de niveau recherche, publiés ou non, émanant des établissements d'enseignement et de recherche français ou étrangers, des laboratoires publics ou privés. 


\title{
Characterization of solar fuels obtained from beech wood solar pyrolysis
}

\author{
Kuo Zeng ${ }^{\mathrm{a}}$, Daniel Gauthier ${ }^{\mathrm{a}}$, Doan Pham Minh ${ }^{\mathrm{b}}$, Elsa Weiss-Hortala ${ }^{\mathrm{b}}$, Ange Nzihou ${ }^{\mathrm{b}}$, Gilles Flamant ${ }^{\mathrm{a}, *}$ \\ a Processes, Materials and Solar Energy Laboratory, PROMES-CNRS, 7 rue du Four Solaire, 66120 Odeillo Font Romeu, France \\ ${ }^{\mathrm{b}}$ Université de Toulouse, Mines Albi, UMR CNRS 5302, Centre RAPSODEE, Campus Jarlard, F-81013 Albi cedex 09, France
}

\section{H I G H L I G H T S}

- Solar pyrolysis of beech wood was carried out with temperature from 600 to $2000^{\circ} \mathrm{C}$.

- Solar fuels (gas, char and oil) were characterized at different temperatures.

- High temperature favors the tar secondary reaction into $\mathrm{H}_{2}$ and $\mathrm{CO}$ formation.

- The char and oil characterization highly depends on pyrolysis temperature.

- The biomass energy is $38-53 \%$ upgraded by the solar pyrolysis process.
G R A P H I C A L A B S T R A C T

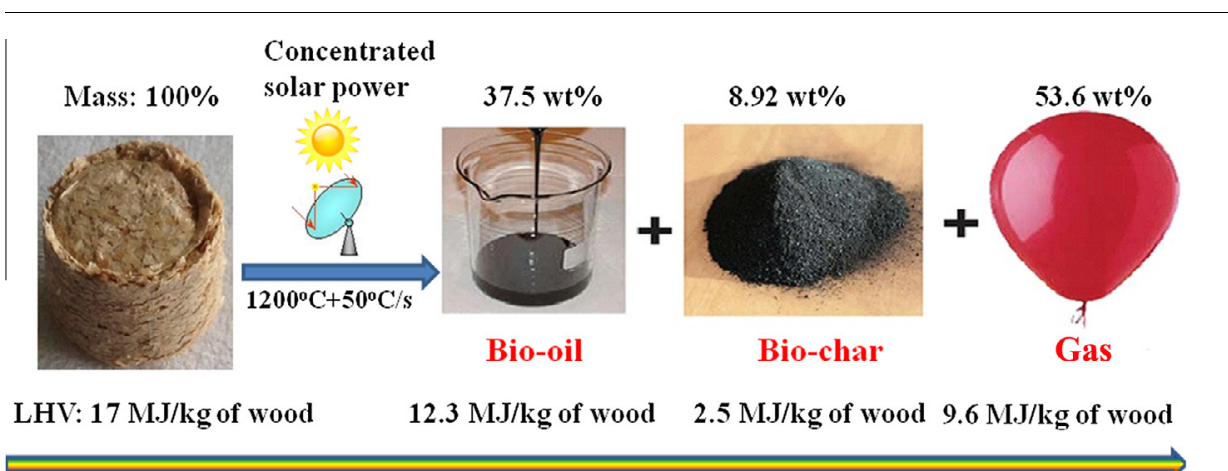

Fifty percent upgrading of biomass energy by solar pyrolysis

\begin{abstract}
A B S T R A C T
Solar pyrolysis of biomass is a smart way to upgrade biomass and, thus, store intermittent solar energy as solar fuels (gas, bio-char and bio-oil). Distribution and energy content of gas, char and oil depend on experimental conditions. In order to determine these characteristics, experiments have been performed at temperatures of $600,900,1200$ and $2000{ }^{\circ} \mathrm{C}$, heating rate of $50{ }^{\circ} \mathrm{C} / \mathrm{s}$ and argon flow rate of $6 \mathrm{NL} / \mathrm{min}$. The gas product was analyzed by micro-GC. The char product was characterized by CHNS, whereas the oil product was subjected to CHNS, Karl-Fischer titration and GC-MS analysis. The LHVs (lower heating values) for gas, char and oil were determined from empirical equations. The gas product yield and LHV significantly increase with temperature, which is mainly due to more $\mathrm{H}_{2}$ and $\mathrm{CO}$ formation by the enhanced secondary tar reactions. The char and oil characteristics highly depend on the temperature. Their high energy contents show that the obtained char and oil can be utilized as valuable solid and liquid fuels. The biomass energy upgrading due to solar processing is discussed. At optimum temperature $900{ }^{\circ} \mathrm{C}$, it ranges from $38 \%$ to $53 \%$ accounting for the uncertainty of bio-oil water content.
\end{abstract}

\section{Introduction}

Currently, more than $80 \%$ of the world's overall energy needs are provided by fossil fuels [1]. With the population and economy growth, global energy demand is expected to increase by $37 \%$ in 2040. Then, for matching the long term energy demand while lim-

\footnotetext{
* Corresponding author.

E-mail address: gilles.flamant@promes.cnrs.fr (G. Flamant).
}

iting $\mathrm{CO}_{2}$ emissions, more and more renewable sources, such as biomass and solar energy should be utilized. Indeed, they represent only a very small portion of the energy supply now [2]. Biomass contributes only about $9 \%$ for the world's energy needs, and solar energy represents less than $1.0 \%$ of the primary energy supply in the world [3]. Between 2010 and 2040 significant developments in renewable energy production will be observed in biomass energy (from 45217.44 to $136950.23 \mathrm{PJ}$ ) and solar energy (from 184.22 to $55768.18 \mathrm{PJ}$ ) [4]. 


\begin{tabular}{|c|c|c|c|}
\hline \multicolumn{2}{|c|}{ Latin letters } & \multicolumn{2}{|c|}{ Subscripts } \\
\hline HHV & higher heating value, $\mathrm{MJ} / \mathrm{kg}$ & $\mathrm{C}$ & carbon \\
\hline LHV & lower heating value, $\mathrm{MJ} / \mathrm{kg}$ & $\mathrm{H}$ & hydrogen \\
\hline Z & mass fraction (dry basis), wt.\% & $\mathrm{O}$ & oxygen \\
\hline M & moisture content, wt.\% & $\mathrm{N}$ & nitrogen \\
\hline $\mathrm{U}$ & upgrade factor, - & $\mathrm{S}$ & sulfur \\
\hline $\mathrm{m}$ & mass, kg & A & ash \\
\hline Q & energy content, MJ & oil & bio-oil product \\
\hline \multirow{2}{*}{\multicolumn{2}{|c|}{ Greek letter }} & gas & gas product \\
\hline & & char & bio-char product \\
\hline & efficiency, - & $\begin{array}{l}\text { biomass } \\
\text { solar }\end{array}$ & $\begin{array}{l}\text { biomass feedstock } \\
\text { solar energy }\end{array}$ \\
\hline
\end{tabular}

However, there are some drawbacks restricting their usage and development. On the one hand, the low energy density biomass is distributed in a wide range of remote areas. On the other hand, the intermittent solar energy is a diluted and unequally distributed source. One way for breaking these barriers is to combine these two sources. In such a process, the concentrated solar radiation supplies high-temperature process heat for biomass pyrolysis reactions [5]. Then biomass and solar energy can be converted into transportable and dispatchable solar fuels [6]. Solar processes have the potential to produce higher calorific value products with lower $\mathrm{CO}_{2}$ emission compared with conventional pyrolysis [7]. The biomass energy is upgraded through solar energy providing pyrolysis reaction enthalpy transferred into products.

The concentrated radiation has been tentatively used since a long time to drive the carbonaceous materials pyrolysis. In the 1980s, Beatie et al. [8] obtained a maximum gas yield of $31 \mathrm{mmol} / \mathrm{g}$ coal from direct solar pyrolysis at solar flux level of $1 \mathrm{MW} / \mathrm{m}^{2}$. Antal et al. [9] developed a reactor for achieving flash pyrolysis of biomass: free-falling particles were heated by concentrated solar energy in a transparent tube. They obtained 26\% gas yield containing $47.5 \% \mathrm{CO}, 22 \% \mathrm{H}_{2}, 13 \% \mathrm{CH}_{4}, 11 \% \mathrm{CO}_{2}$ and $4.3 \%$ $\mathrm{C}_{2} \mathrm{H}_{4}$ with fractions of light hydrocarbons $\left(\mathrm{C}_{3}\right.$ and $\left.\mathrm{C}_{4}\right)$. Tabatabaie-Raissi et al. [10] got 6.6-8.4\% char yield from pyrolysis of cellulose under radiation flux density up to $10 \mathrm{MW} / \mathrm{m}^{2}$ in a TGA. Chan et al. [11] investigated the pyrolysis of pinewood with a solar simulator and found that the char, tar and gas yields were $20-26 \%$, $33-52 \%$ and $11-27 \%$, respectively, depending on the flux density. Later, $21-29 \%$ char, $25-40 \%$ tar and $30-50 \%$ gas yields have been reported for radiative pyrolysis of different woods under concentrated lamp radiation $\left(0.08\right.$ and $\left.0.13 \mathrm{MW} / \mathrm{m}^{2}\right)$ [12]. Lédé et al. [13] found an almost stable $62 \%$ of liquid yield with various heat flux densities (from 0.3 to $0.8 \mathrm{MW} / \mathrm{m}^{2}$ ). Recently, the application of an image furnace (simulating solar radiation) for biomass pyrolysis has been reported [14]. At the same time, the concept of a fix bed reactor heated by a vertical axis solar furnace has been well investigated because of the special interest in the solar pyrolysis of beech wood at CNRS-PROMES [15-17]. Besides, the parabolictrough solar collector [18] and Fresnel lens [19] were also used to produce bio-oil through pyrolysis.

Solar pyrolysis of carbonaceous materials leads to the formation of gases, bio-oil and bio-char. Gas products can be applied for heat and power production or precursors for chemicals [20]. Bio-oil can be transported and stored for further use in boilers or engines for energy and heat generation [21]. Char can be used as a fuel or adsorbent [22]. The solar pyrolysis bio-oil has already been characterized by some researchers $[18,19]$. It only shows one part of the energy content from solar pyrolysis products. The solar pyrolysis product characteristics at different temperatures have yet to be reported. The conversion of carbonaceous materials to higher valued solar fuels by solar pyrolysis can be attractive, but at which temperature should the feedstock be handled? Solar gas, bio-char and bio-oil compositions and energy contents (LHV) are presented in this paper. Moreover, the biomass energy upgrade factor, which is a very important indicator for biomass conversion, is determined at different temperatures for the first time.

\section{Experimental section}

\subsection{Biomass feedstock}

Beech wood pellets (about $0.3 \mathrm{~g}$ ), $10 \mathrm{~mm}$ in diameter and $5 \mathrm{~mm}$ high were used in experiments. The beech wood characteristics are shown in Table 1.

\subsection{Solar pyrolysis experiments}

\subsubsection{Solar experimental setup}

Solar pyrolysis experiments were run in a vertical-axis solar furnace shown in Fig. 1. A down-facing parabolic mirror $(2 \mathrm{~m}$ diameter and $0.85 \mathrm{~m}$ focal length) is illuminated by the reflected beam issued from the heliostat. The maximum power and maximum flux density are approximately $1.5 \mathrm{~kW}$ and $12,000 \mathrm{~kW} / \mathrm{m}^{2}$, respectively. A shutter placed between the heliostat and the parabola modulates the reflected solar beam, and thus the concentrated radiation. The beech wood pellet set in a graphite crucible is located in a $6 \mathrm{~L}$ transparent Pyrex balloon reactor swept with an argon flow. A "solar-blind" optical pyrometer (KLEIBER monochromatic operating at $5.2 \mu \mathrm{m}$ ) is used to measure the pellet surface temperature. Based on the measured temperature, the shutter opening controlled by PID controller is adjusted to reach the target heating rate and final temperature. The argon flow in the reactor is

Table 1

The characteristics of beech wood.

\begin{tabular}{|c|c|c|c|c|c|c|c|c|}
\hline \multicolumn{4}{|c|}{ Proximate analysis } & \multicolumn{5}{|c|}{ Ultimate analysis } \\
\hline $\begin{array}{l}\text { Volatile matter } \\
\text { \%mass, dry }\end{array}$ & Fixed carbon & Ash & $\begin{array}{l}\text { Moisture } \\
\% \text { mass }\end{array}$ & $\begin{array}{l}\mathrm{C} \\
\text { \%mass }\end{array}$ & $\mathrm{H}$ & 0 & $\mathrm{~N}$ & $\mathrm{~S}$ \\
\hline 85.3 & 14.3 & 0.4 & 6 & 50.8 & 5.9 & 42.9 & 0.3 & 0.02 \\
\hline
\end{tabular}


(a)

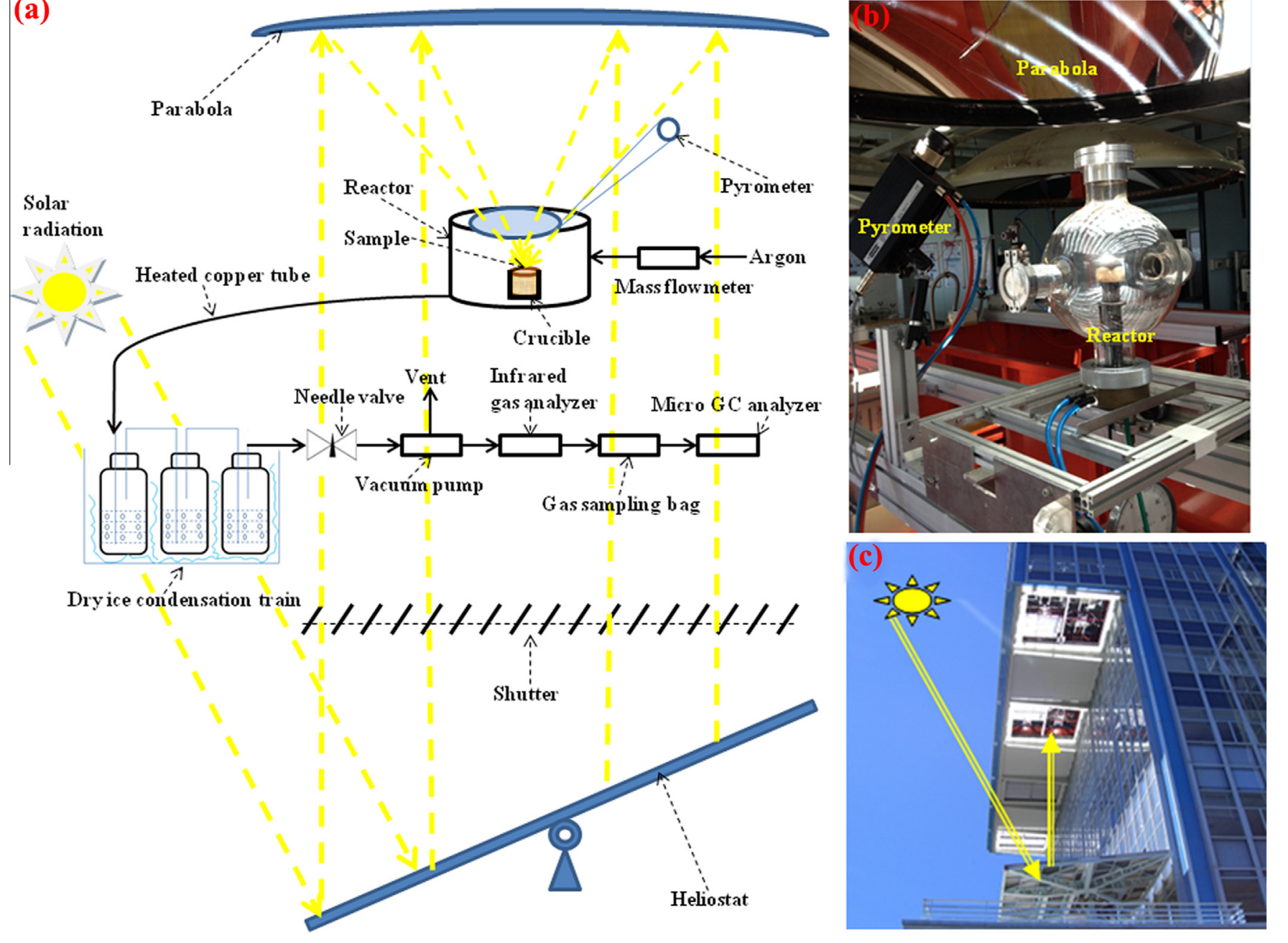

Fig. 1. Schematic of the solar pyrolysis experimental setup: (a) whole system, (b) solar reactor and (c) vertical solar furnace.

controlled by a mass flowmeter (Bronkhorst, EL-FLOW ${ }^{\circledR}$ ). A 3100 SYNGAS analyzer is used to on-line monitor the oxygen concentration during vacuum process.

The pyrolysis products (condensable vapors and incondensable gases) firstly circulate through a $250{ }^{\circ} \mathrm{C}$ heated copper tube (to avoid unwanted deposit before collection). Then they pass through a dry ice condensation train composed of three impinger bottles, which are immersed in dry ice (temperature between around $-25^{\circ} \mathrm{C}$ and $-15^{\circ} \mathrm{C}$ ). Each bottle contains about $100 \mathrm{ml}$ of isopropanol solvent (2-propanol) for higher tar capture efficiency and further GC-MS analysis. A needle valve and a vacuum pump are set downstream the condensation train. The permanent gases are collected in a sampling bag through the vacuum pump. After that, the outlet gas composition is determined by gas chromatography (SRA Instruments MicroGC 3000).

\subsubsection{Products recovery and characterization}

Solar pyrolysis of biomass was carried out under the following conditions: heating rate of $50{ }^{\circ} \mathrm{C} / \mathrm{s}$, absolute pressure of $0.44 \mathrm{bar}$, and argon flow rate of $6 \mathrm{NL} / \mathrm{min}$. The final temperatures were constant for $5 \mathrm{~min}$. All experiments were done at least 3 times to guarantee the repetability. Then, the error bars in plots indicate $95 \%$ confidence intervals.

After sampling, all liquid (the mixture of isopropanol solvent and bio-oil) in impinge bottles was removed to a beaker and heated to $83^{\circ} \mathrm{C}$ till all the solvent was evaporated. The bio-char was weighed and characterized as in our previous studies [15]. The gas yield was calculated according to the Ideal Gas Law with the measured gas compositions as described previously [16]. The bio-oil yield was determined by mass balance. The elemental composition (CHNS) of bio-oil was determined by NA 2100 protein. The bio-oil water content was measured by the Karl-Fisher (K-F) titration (ASTM E 203 standard), using a Mettler Toledo V30 apparatus. The chemical compounds in the bio-oil were determined with gas chromatography-mass spectrometry (GC-MS). The GCMS analysis was conducted with a Shimadzu GC-2010 Plus gas chromatograph coupled to a Shimadzu GCMS-TQ8030 mass spectrometer. The carrier gas used was He 5.0 with a linear velocity of $35 \mathrm{~cm} \mathrm{~s}^{-1}$. Mass spectra were obtained using a quadripole analyzer with $70 \mathrm{eV}$ electron impact (EI) ionization between 40 and 600 a.m.u.

\section{Results and discussion}

\subsection{Final product distribution}

Bio-char, Bio-oil and gas yields were determined at four final temperatures: $600,900,1200$ and $2000{ }^{\circ} \mathrm{C}$ (Fig. 2). The bio-oil and bio-char yields decreased, whereas the gas yield increased when temperature increased. The change was abrupt between 900 and $1200{ }^{\circ} \mathrm{C}$. $62.4 \%$ bio-oil and $16.8 \%$ bio-char were yielded at $600{ }^{\circ} \mathrm{C}$, whereas at $900{ }^{\circ} \mathrm{C} 57.7 \%$ bio-oil and $13.3 \%$ bio-char were 


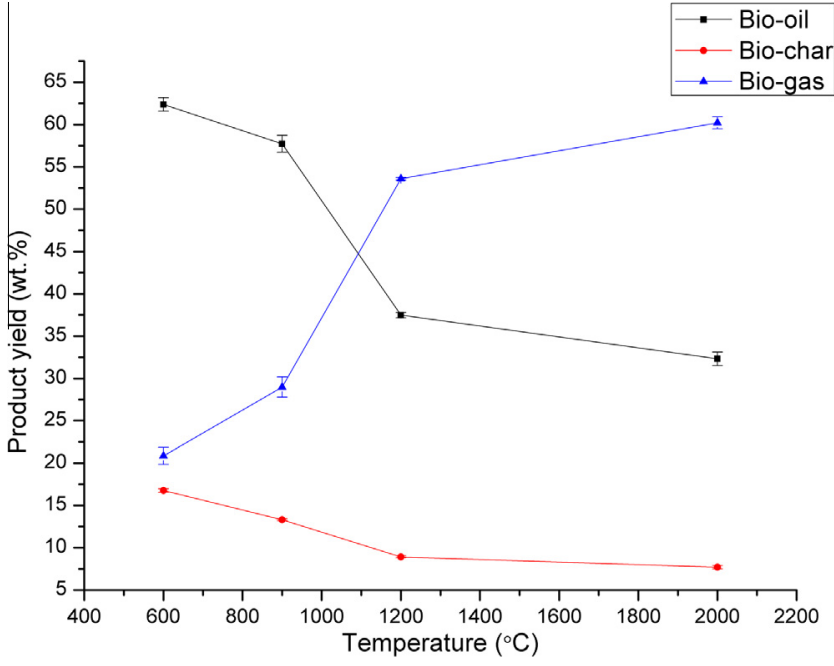

Fig. 2. Products' distribution as a function of temperature.

obtained through solar pyrolysis. Secondary cracking of primary tar and bio-char decomposition caused the gas yield growth from $20.9 \%$ at $600{ }^{\circ} \mathrm{C}$ to $29.0 \%$ at $900{ }^{\circ} \mathrm{C}$. When the temperature increased to $1200^{\circ} \mathrm{C}$, the gas yield rapidly increased to $53.6 \%$. This gas yield increase was mainly due to the secondary tar reactions, since there was a sharp decrease of bio-oil yield to $37.5 \%$ [23]. However, the gas yield only slightly changed to $60.2 \%$ at temperature of $2000{ }^{\circ} \mathrm{C}$. The slighter gas yield increase may be attributed to less tar degradation at temperature higher than $1200^{\circ} \mathrm{C}$. The char yield (with error bars) kept almost constant as about $8 \%$ at temperature higher than $1200^{\circ} \mathrm{C}$, which was also reported by Neves et al. [24].

\subsection{Pyrolysis gas composition}

The biomass pyrolysis gases are a mixture of $\mathrm{CO}, \mathrm{H}_{2}, \mathrm{CH}_{4}, \mathrm{CO}_{2}$ and other light hydrocarbons. They are released mainly from biomass main components (hemicellulose, cellulose and lignin) degradation. Their interactions and secondary tar reaction at higher temperatures also influence the gas yields and composition. The pyrolysis is controlled by secondary reactions (gas phase reactions) when the temperature is above $560{ }^{\circ} \mathrm{C}$ [25]. It means that the gas composition of solar pyrolysis (from 600 to $2000{ }^{\circ} \mathrm{C}$ ) mainly depends on gas phase reactions. Some of the possible gas phase reactions involved in solar pyrolysis are generally listed as follow:

$\mathrm{C}+\mathrm{CO}_{2} \leftrightarrow 2 \mathrm{CO} \quad \Delta \mathrm{H}_{298}^{0}=+168 \mathrm{MJ} / \mathrm{kmol}$,

$\mathrm{C}+\mathrm{H}_{2} \mathrm{O} \leftrightarrow \mathrm{CO}+\mathrm{H}_{2} \quad \Delta \mathrm{H}_{298}^{0}=+175 \mathrm{MJ} / \mathrm{kmol}$

$\mathrm{CH}_{4}+\mathrm{H}_{2} \mathrm{O} \leftrightarrow \mathrm{CO}+3 \mathrm{H}_{2} \quad \Delta \mathrm{H}_{298}^{0}=+206 \mathrm{MJ} / \mathrm{kmol}$

$\mathrm{CH}_{4}+2 \mathrm{H}_{2} \mathrm{O} \leftrightarrow \mathrm{CO}_{2}+4 \mathrm{H}_{2} \quad \Delta \mathrm{H}_{298}^{0}=+165 \mathrm{MJ} / \mathrm{kmol}$

$\mathrm{CO}+\mathrm{H}_{2} \mathrm{O} \leftrightarrow \mathrm{CO}_{2}+\mathrm{H}_{2} \quad \Delta \mathrm{H}_{298}^{0}=-41 \mathrm{MJ} / \mathrm{kmol}$

$\mathrm{C}+2 \mathrm{H}_{2} \leftrightarrow \mathrm{CH}_{4} \quad \Delta \mathrm{H}_{298}^{0}=-75 \mathrm{MJ} / \mathrm{kmol}$

$\left[\mathrm{C}_{x} \mathrm{H}_{y} \mathrm{O}_{z}\right] \rightarrow \mathrm{C}+\mathrm{Tar}+\mathrm{CO}+\mathrm{H}_{2}+\mathrm{CH}_{4}+\mathrm{C}_{n} \mathrm{H}_{m}$

$\left[\mathrm{C}_{x} \mathrm{H}_{y} \mathrm{O}_{z}\right]+\mathrm{H}_{2} \mathrm{O} \rightarrow \mathrm{CO}+\mathrm{H}_{2}+$ Tar

$\left[\mathrm{C}_{x} \mathrm{H}_{y} \mathrm{O}_{z}\right]+\mathrm{CO}_{2} \rightarrow \mathrm{CO}+\mathrm{H}_{2} \mathrm{O}+\mathrm{Tar}$ where $\left[\mathrm{C}_{x} \mathrm{H}_{y} \mathrm{O}_{z}\right]$ indicates the intermediate tar phase, $\mathrm{C}$ represents the solid product (char or coke), and tar stands for the liquid product (secondary or tertiary tar). It should be clarified that tar thermal cracking dominated the solar pyrolysis gas phase reaction process at temperatures exceeding $600^{\circ} \mathrm{C}$ listed as reaction (7).

As can be seen in Fig. 3, the gas composition varies with temperature. $\mathrm{H}_{2}$ and $\mathrm{C}_{2} \mathrm{H}_{6}$ mainly come from the secondary tar cracking reaction (7), and they were not detected at $600{ }^{\circ} \mathrm{C}$, similarly to previous results [26]. Increasing temperature to $900{ }^{\circ} \mathrm{C}$ leads to $\mathrm{H}_{2}$ and CO molar yields increasing from 0 to $2.65 \mathrm{~mol} / \mathrm{kg}$ of wood and from 4.08 to $6.61 \mathrm{~mol} / \mathrm{kg}$ of wood caused by reactions (1) and (5), respectively, At the same time, $\mathrm{CO}_{2}$ molar yield decreases from 1.81 to $1.32 \mathrm{~mol} / \mathrm{kg}$ of wood. A similar trend in syngas yield from mangrove pyrolysis was reported by Ahmed et al. [27]. Further temperature increment to $1200{ }^{\circ} \mathrm{C}$ caused obvious $\mathrm{H}_{2}$ and $\mathrm{CO}$ yield increase to 12.35 and $14.26 \mathrm{~mol} / \mathrm{kg}$ of wood. Since the temperature increase favors endothermic reactions, reactions (1)-(4) [25] and tar secondary reactions (7)-(9) [28] shifted to the right, thus producing more $\mathrm{H}_{2}$ and $\mathrm{CO}$. It should be clearly noted that intraparticle tar cracking reaction (7) contributes to the largest part of $\mathrm{H}_{2}$ and $\mathrm{CO}$ yields increase. A increase from 0.91 to $2.45 \mathrm{~mol} / \mathrm{kg}$ of wood was observed for $\mathrm{CH}_{4}$ yield with temperature rising from 600 to $1200{ }^{\circ} \mathrm{C}$ owing to the tar cracking reaction (7) [29]. However, it reduced to $0.87 \mathrm{~mol} / \mathrm{kg}$ of wood because of more cracking reaction (6) [30] and steam gasification reaction (3) at very high temperature $\left(2000^{\circ} \mathrm{C}\right)$.

\subsection{Bio-char characterization}

Fig. 4 shows char molar composition at different temperatures. Char was composed primarily of carbon with molar content higher than $60 \%$. The linear fit of $\mathrm{C}$ and $\mathrm{H}$ molar contents indicate the sharp increase of carbon content and the sharp decrease of hydrogen content with increasing temperature. The carbon increase proves that the carbonization degree is accelerated with rising temperature [31]. Almost completely carbonized char with $100 \%$ carbon content was obtained at $2000^{\circ} \mathrm{C}$ [15]. Obvious losses in hydrogen and oxygen contents came from the breaking and cleavage of char weak bonds [32].

Fig. 5 is a Van Krevelen plot showing the $\mathrm{H} / \mathrm{C}$ and $\mathrm{O} / \mathrm{C}$ atomic ratios as a function of pyrolysis temperature. A decrease in the $\mathrm{H} / \mathrm{C}$ and $\mathrm{O} / \mathrm{C}$ ratios, from 0.03 and 0.27 for Biochar-600 down to 0 and 0 for Biochar-2000 was observed. The decrease of $\mathrm{H} / \mathrm{C}$ and $\mathrm{O} / \mathrm{C}$ ratios of solar pyrolysis bio-chars resulted from the enhanced oligosaccharides dehydration, decarboxylation, demethanation

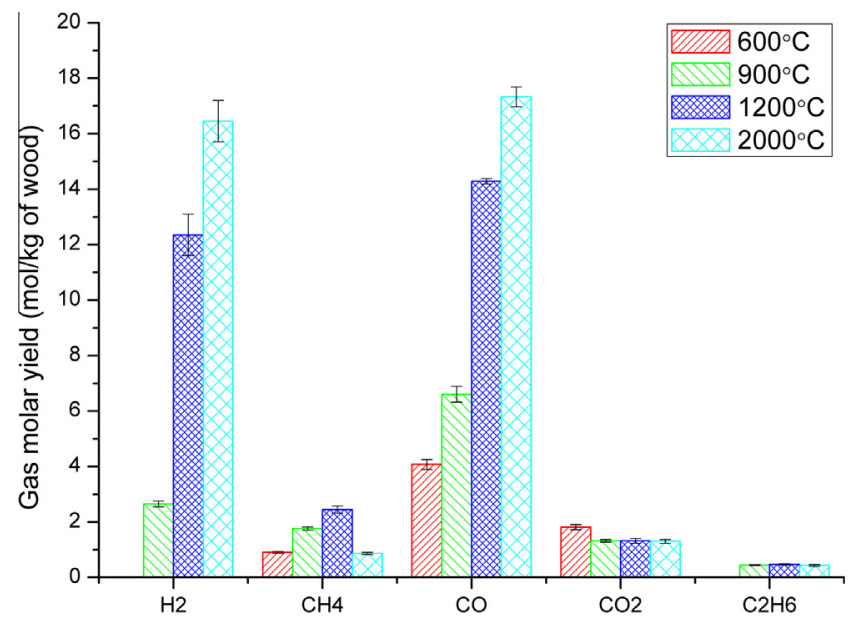

Fig. 3. Gas composition as a function of temperature. 


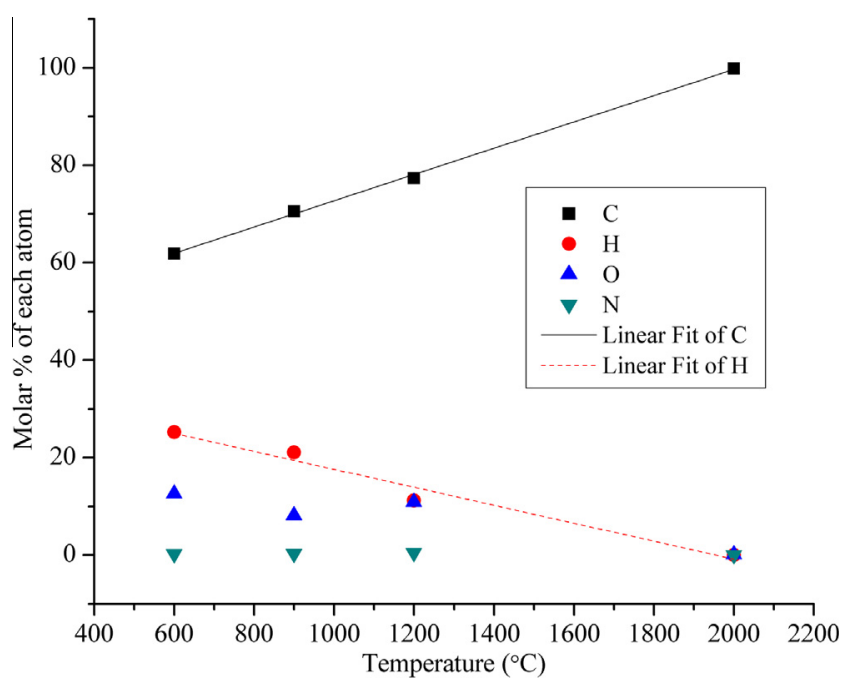

Fig. 4. Char molar composition at different temperatures.

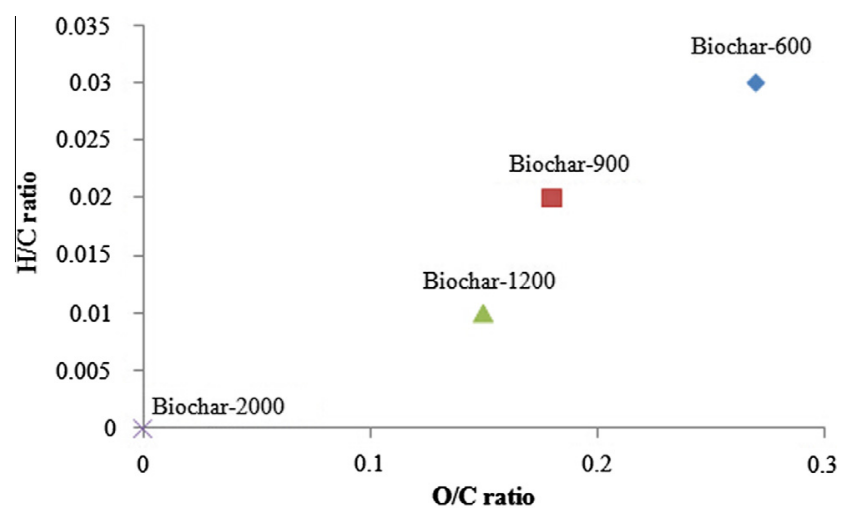

Fig. 5. Van Krevelen plots of biochars produced at various temperatures (Biochar600 , Biochar-900, Biochar-1200 and Biochar-2000 are the biochars produced at pyrolysis temperatures of $600^{\circ} \mathrm{C}, 900^{\circ} \mathrm{C}, 1200^{\circ} \mathrm{C}$ and $2000^{\circ} \mathrm{C}$, respectively).

and decarbonylation at higher pyrolysis temperatures [33]. A significant higher $\mathrm{H} / \mathrm{C}$ atomic ratio was observed in bio-char obtained from conventional fast pyrolysis at $550{ }^{\circ} \mathrm{C}$ (about 0.45 ). It indicates the solar pyrolysis bio-chars' partial continuous transformation from aromatic to graphitic structures (particular to black carbon) compared to the bio-chars obtained from the conventional fast pyrolysis process.

\subsection{Bio-oil characterization}

\subsubsection{Bio-oil properties}

Table 2 gives the properties of the solar pyrolysis bio-oils generated from beech wood pyrolysis at the considered temperatures. The $\mathrm{C}, \mathrm{H}, \mathrm{N}$ and $\mathrm{S}$ contents were directly determined with CHNS, while $\mathrm{O}$ content was calculated by difference. The bio-oil higher heating value (HHV) was calculated according to Eq. (10) [34]. Its lower heating value (LHV) was calculated from the HHV and the moisture content by Eq. (11) [35].

$$
H H V=0.35 Z_{C}+1.18 Z_{H}-0.10 Z_{0}-0.02 Z_{N}+0.10 Z_{S}-0.02 Z_{A}
$$

$L H V=H H V(1-M)-2.447 M$

The water content was $1.67 \%$ for bio-oil obtained at $900{ }^{\circ} \mathrm{C}$ and $1.15 \%$ for that obtained at $2000{ }^{\circ} \mathrm{C}$. We found no obvious effect of temperature on the bio-oil water content. The small reduction of bio-oil moisture content at $2000{ }^{\circ} \mathrm{C}$ may be explained by the water consumption due to the gasification reaction at higher temperature. When comparing with results from others, the solar pyrolysis bio-oil has lower water content than conventional pyrolysis biooil, which is suitable as a fuel. As shown in Table 2, temperature has no obvious influence on the element concentrations of solar pyrolysis bio-oil. The carbon content is around 58\%, and the oxygen content in the bio-oil is lower than that in the feedstock, since $\mathrm{O}$ content is splitted into NCG gases $\left(\mathrm{CO}_{2}\right.$ and $\left.\mathrm{CO}\right)$ through pyrolysis [36]. The hydrogen content in solar pyrolysis bio-oil is about twice higher than that in conventional pyrolysis bio-oil, thus doubling the HHV. The low oxygen and high hydrogen contents make solar pyrolysis bio-oil be a attractive fuel [37]. Calculated HHV and LHV for solar pyrolysis bio-oils obtained at temperatures 600 and $900{ }^{\circ} \mathrm{C}$ are around 31 and $30 \mathrm{MJ} / \mathrm{kg}$, respectively. They increase to 33 and $32 \mathrm{MJ} / \mathrm{kg}$ for temperatures 1200 and $2000{ }^{\circ} \mathrm{C}$, respectively, due to the hydrogen content increase with temperature. The solar pyrolysis bio-oil LHV is about $68 \%$ of crude oil LHV, due to its lower carbon content and higher oxygen content.

\subsubsection{Bio-oil compounds}

Solar pyrolysis bio-oils collected at $600,900,1200$ and $2000{ }^{\circ} \mathrm{C}$ were analyzed by gas chromatography-mass spectrometry (GC/MS). Bio-oils obtained from 600 to $1200^{\circ} \mathrm{C}$ are very complex mixtures of C4-C26 organic compounds. It turns into mainly a C6-C16 compound mixture at $2000{ }^{\circ} \mathrm{C}$, because of the long-chain tars thermal cracking at higher temperature [38]. Most abundant products are considered as compounds with peak areas near or greater than $2 \%$ [21]. The most abundant tar compounds resulting from solar pyrolysis are shown in Table 3. It can be seen that the

Table 2

Properties of the solar pyrolysis bio-oil.

\begin{tabular}{|c|c|c|c|c|c|c|}
\hline Composition & $600^{\circ} \mathrm{C}$ Bio-oil & $900^{\circ} \mathrm{C}$ Bio-oil & $1200^{\circ} \mathrm{C}$ Bio-oil & $2000^{\circ} \mathrm{C}$ Bio-oil & Typical bio-oil [48] & Crude oil [48] \\
\hline Water (wt.\%) & 1.43 & 1.67 & 1.51 & 1.15 & $15-30$ & 0.1 \\
\hline Density $(\mathrm{kg} / \mathrm{L})$ & - & - & - & - & $1.05-1.25$ & $0.86-0.94$ \\
\hline Viscosity $50^{\circ} \mathrm{C}(\mathrm{cP})$ & - & - & - & - & $40-100$ & 180 \\
\hline HHV (MJ/kg of tar) & 30.74 & 30.73 & 33.24 & 33.11 & $16-19$ & 44 \\
\hline LHV (MJ/kg of tar) & 30.26 & 30.18 & 32.70 & 32.70 & - & 44 \\
\hline C (wt.\%) & 58.1 & 57.4 & 58.8 & 58.6 & $55-65$ & 83.86 \\
\hline $\mathrm{O}$ (wt.\%) & 30.16 & 30.61 & 27.7 & 27.88 & $28-40$ & $<1$ \\
\hline $\mathrm{H}(\mathrm{wt} . \%)$ & 11.37 & 11.61 & 13.08 & 13.04 & $5-7$ & $11-14$ \\
\hline S (wt.\%) & 0.0826 & 0.0835 & 0.0357 & 0.0658 & $<0.05$ & $<4$ \\
\hline $\mathrm{N}(\mathrm{wt} . \%)$ & 0.37 & 0.38 & 0.42 & 0.48 & $<0.4$ & $<1$ \\
\hline Ash (wt.\%) & - & - & - & - & $<0.2$ & 0.1 \\
\hline $\mathrm{H} / \mathrm{C}$ & 2.35 & 2.43 & 2.67 & 2.67 & $0.9-1.5$ & $1.5-2.0$ \\
\hline $\mathrm{O} / \mathrm{C}$ & 0.39 & 0.4 & 0.35 & 0.36 & $0.3-0.5$ & $\sim 0$ \\
\hline
\end{tabular}




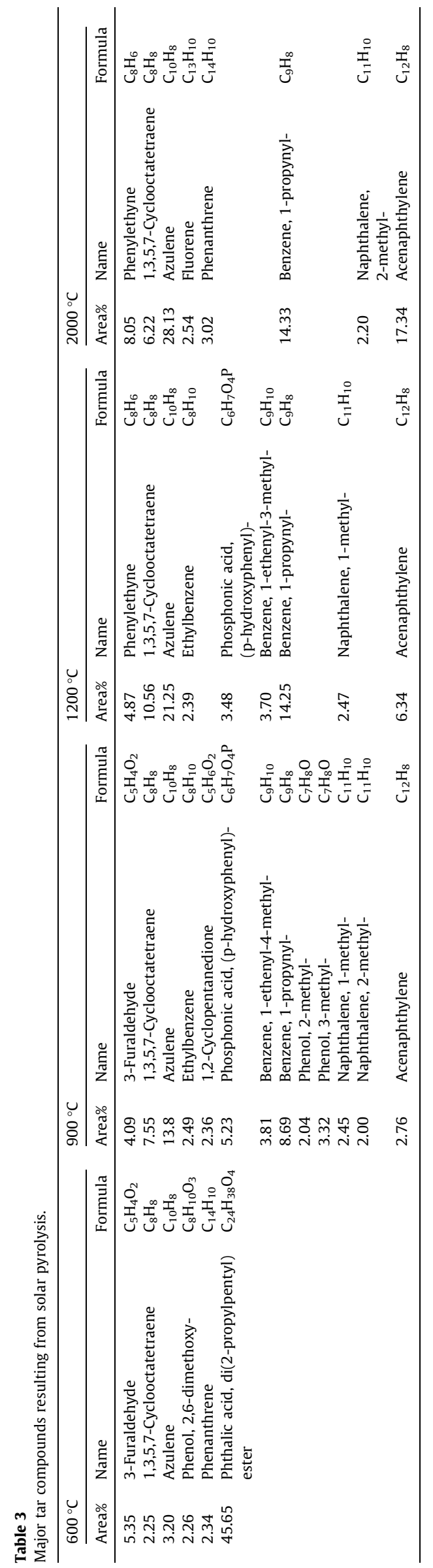

bio-oil produced at $600{ }^{\circ} \mathrm{C}$ contains high concentration of compounds such as phthalic acid, 3-furaldehyde, azulene, phenol, 2,6-dimethoxy- and 1,3,5,7-cyclooctatetraene. Mourant et al. [39] have reported similar high acid concentration from fast pyrolysis of wood at $500{ }^{\circ} \mathrm{C}$. Oxygen-rich primary tars like acids are mainly formed from the high oxygen content cellulose and hemicellulose degradation at low temperature [40]. When the temperature increases from 600 to $800^{\circ} \mathrm{C}$, more and more secondary tars such as phenols are produced by primary tar breakage, decarboxylation, decarbonylation [41] and dehydrogenation after Diels-Alder reactions [28]. Over $800^{\circ} \mathrm{C}$, lower aromatic molecules such as benzene are generated by dealkylation and dehydroxylation reactions [42]. Light tars like phenol and benzene are precursors for heavy tars (tertiary tar). At $900{ }^{\circ} \mathrm{C}$, benzene, 1-ethenyl-4-methyl-, benzene, 1-propynyl-, phenol, 2-methyl- and phenol, 3-methyl-, naphthalene and acenaphthylene appear as main compounds in solar pyrolysis bio-oil indicated in Table 3. It is explained by: (1) two aromatic species direct combination producing a dimer [43] and (2) polyaromatic compounds (PAH) formation due to aromatic rings added by light unsaturated hydrocarbons [44]. These two processes are enhanced with increasing temperature. Then azulene, benzene, 1-propynyl- and acenaphthylene increased a lot when temperature reached $1200^{\circ} \mathrm{C}$. At extreme high temperature $\left(2000^{\circ} \mathrm{C}\right)$, heavy tars like acenaphthylene strongly increased caused by PAH growth [45]. There is no oxygen-containing compound detected at $2000^{\circ} \mathrm{C}$ due to their destruction at high temperatures [46]. Other primary, secondary and tertiary tars may be formed at contents lower than the GC/MS detection limit.

The number of compound species detected by GC/MS is plotted versus temperature in Fig. 6. From 600 to $900{ }^{\circ} \mathrm{C}$, the number of identified tar species increases from about 52 to 71 . This can be explained by more kinds of secondary, tertiary species and heavy tar formation. From 900 to $1200^{\circ} \mathrm{C}$, it slightly decreases to 69 due to the tar (both light and heavy) destruction at high temperature. The destruction effect is sharply enhanced at $2000^{\circ} \mathrm{C}$, since the number of identified tar species decreases to 28 .

\subsection{Solar fuels energy evaluation}

\subsubsection{Elemental balance}

The bio-oil mass is calculated from mass balance. Then the elemental balance is checked to determine the analysis accuracy of bio-oil, bio-char and gas. As for $\mathrm{C}, \mathrm{H}$ and $\mathrm{O}$, around $1 \%$ of the initial carbon and $0.17 \%$ of hydrogen are lost for results from pyrolysis experiments at the four considered temperatures. The missing mass formula is therefore $\mathrm{C}_{n} \mathrm{H}_{2 n}$, which is fairly close to $\mathrm{C}_{2} \mathrm{H}_{4}$ or $\mathrm{C}_{2} \mathrm{H}_{6}$. Consequently, it can be assumed that the missing parts consist in light hydrocarbon $\left(\mathrm{C}_{\mathrm{n}} \mathrm{H}_{\mathrm{m}}\right)$ gases, which are not detected by the Micro GC.

\subsubsection{Energy distribution}

It is important to evaluate the energy contained in gas, bio-oil and bio-char because it determines the energy efficiency of the solar processing of biomass. Gas LHV was calculated based on its yield and LHV of $\mathrm{CO}, \mathrm{H}_{2}, \mathrm{CH}_{4}$ and $\mathrm{C}_{2} \mathrm{H}_{6}$. Bio-oil LHV was calculated from Eqs. (10) and (11) indicated in Table 2. Bio-char LHV was determined from Eqs. (10) and (12) [47].

$L H V=H H V-2.442 \times 8.936(H / 100)$

Fig. 7 plots the energy distribution of the solar pyrolysis products at the four considered temperatures. In this figure, the biooil energy is determined based both on the detected water content (in solar bio-oil) and assuming $15 \%$ water content (similarly to typical bio-oil). This assumption was made in order to estimate the LHV uncertainty due to the uncertainty of water content. In our experimental setup, steam condensation on the sample holder 


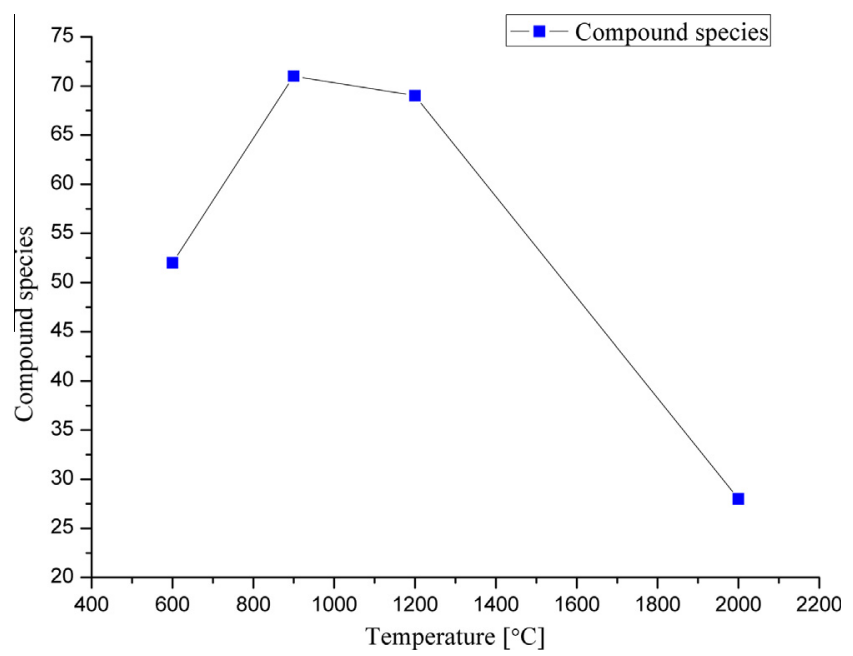

Fig. 6. Bio-oil compound species number detected by GC/MS as a function of temperature.

(water cooling system) and reactor wall may occur. The water content was less than $2 \%$ for solar bio-oil, whereas it is about $15 \%$ for typical conventional pyrolysis bio-oil. Thus the estimation of biooil LHV was carried out from Eq. (11) with water content of $15 \%$.

As the gas yield significantly increases with temperature, the gas energy production at 600 and $900{ }^{\circ} \mathrm{C}$ was significantly lower (1.88 and $4.54 \mathrm{MJ} / \mathrm{kg}$ of wood, respectively) than at 1200 and $2000{ }^{\circ} \mathrm{C}$ (9.62 and $10.14 \mathrm{MJ} / \mathrm{kg}$ of wood, respectively). Besides, the total energy production was slightly higher at 600 and $900{ }^{\circ} \mathrm{C}$ than at higher temperatures $\left(1200\right.$ and $\left.2000^{\circ} \mathrm{C}\right)$. The greater amount of bio-oil (with very high energy value) at lower temperatures may explain this tendency. The bio-oil energy contents at 600 and $900^{\circ} \mathrm{C}$ are significantly higher (16.07-18.88 and 14.86$17.41 \mathrm{MJ} / \mathrm{kg}$ of wood, respectively) than at 1200 and $2000{ }^{\circ} \mathrm{C}$ (10.45-12.26 and $8.91-10.57 \mathrm{MJ} / \mathrm{kg}$ of wood, respectively). Above $1200^{\circ} \mathrm{C}$, the gasification is improved (higher gas yield) and the energetic potential is equally distributed between bio-oil and gas.

\subsubsection{Energy upgrade factor}

The energy upgrade factor is defined as the ratio of the sum of produced bio-oil, gas and bio-char heating values over the heating value of the processed biomass feedstock (beech wood). The upgrade factor can be written as follows:

$U=\frac{m_{\text {oil }} L H V_{\text {oil }}+m_{\text {gas }} L H V_{\text {gas }}+m_{\text {char }} L H V_{\text {char }}}{m_{\text {biomass }} L H V_{\text {biomass }}}$

where $\mathrm{m}$ and LHV indicate mass and lower heating values, respectively.

The beech wood lower heating value was determined as $17 \mathrm{MJ} / \mathrm{kg}$ by GALLENKAMP Auto Adiabatic Bomb Calorimeter according to ASTM D 240. Both the measured and the estimated energy upgrade factors of solar pyrolyzed biomass are plotted versus temperature in Fig. 8. In this figure, the total product energy content is calculated based on the LHV of both as-measured solar bio-oil and assuming $15 \%$ water content (which is the typical composition of standard bio-oil), to represent what may be upper and

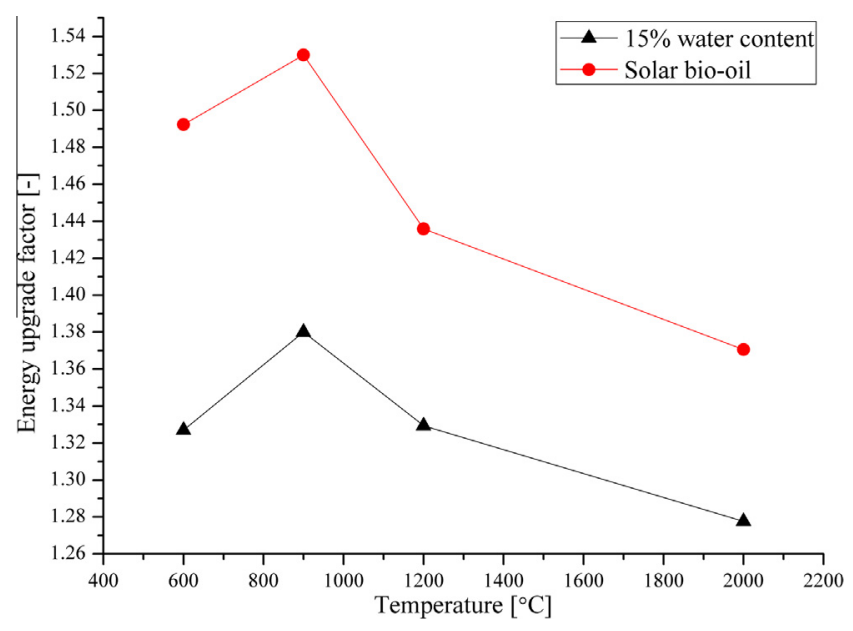

Fig. 8. Energy upgrade factor as a function of temperature.

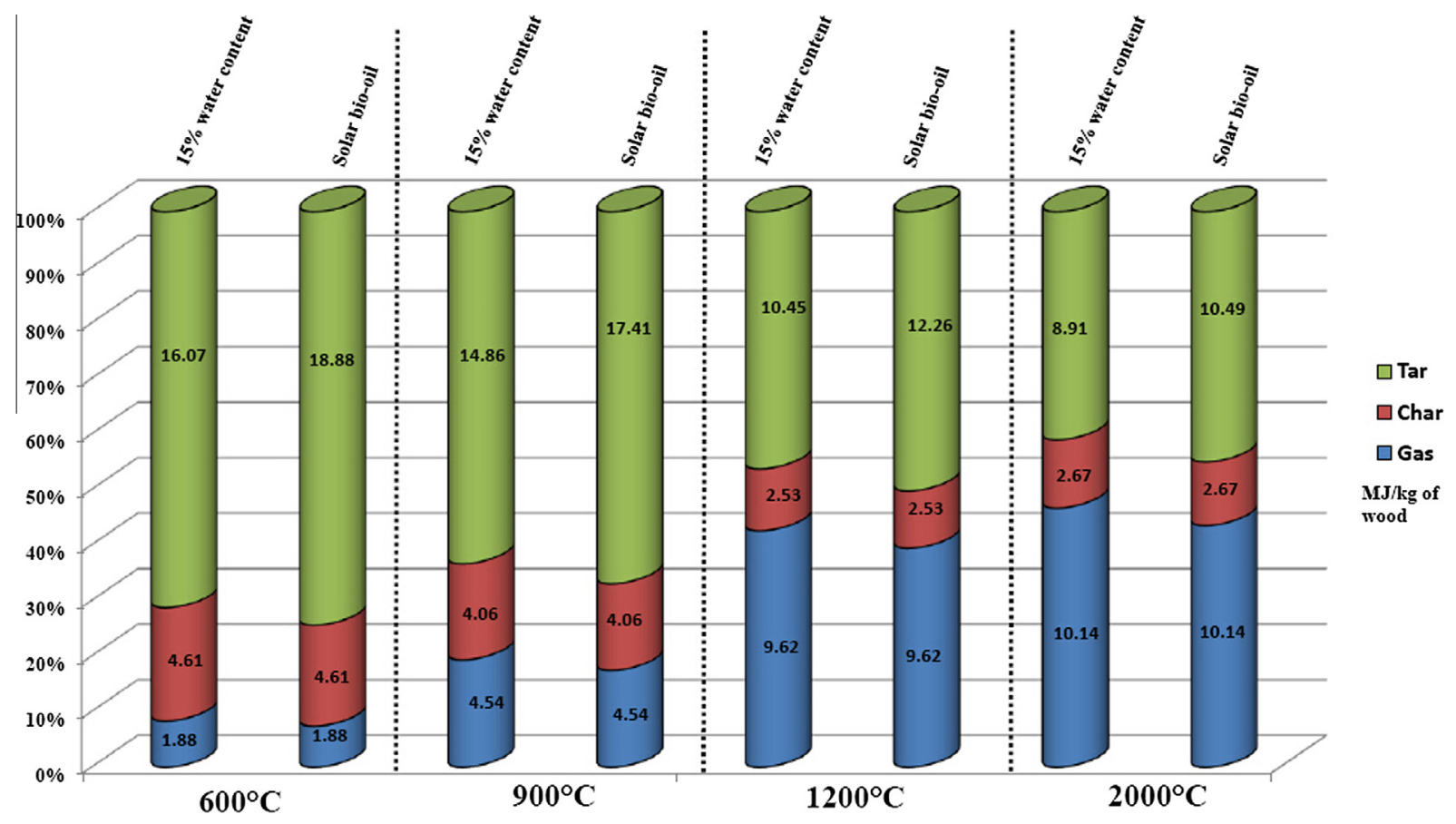

Fig. 7. Solar pyrolysis product energy distribution as a function of temperature. 
Table 4

Energy upgrade factor comparison.

\begin{tabular}{|c|c|c|c|c|}
\hline Process & Feedstock & Upgrade factor & Method & Reference \\
\hline Conventional autothermal gasification & Coal & 0.65 & Calculation & [6] \\
\hline Conventional autothermal pyrolysis & Forest waste & 0.91 & Calculation & [50] \\
\hline Solar gasification & Biomass & 1.188 & Calculation & [7] \\
\hline Solar gasification & Beech charcoal & 1.3 & Experiment & [49] \\
\hline Solar pyrolysis & Beech wood & $1.38-1.53$ & Experiment & This study \\
\hline
\end{tabular}

lower limits. As can be seen, the energy upgrade factor increases from $1.33-1.49$ to $1.38-1.53$ (for $15 \%$ and as-measured water content respectively) when the temperature increases from 600 to $900{ }^{\circ} \mathrm{C}$. Then it slightly decreases to $1.33-1.44$ at $1200{ }^{\circ} \mathrm{C}$, and more significantly to $1.28-1.37$ at $2000^{\circ} \mathrm{C}$. The energy upgrade factor variation is mostly due to the bio-oil yield decrease with temperature.

The biomass energy upgrade factors $U$ for conventional autothermal pyrolysis, conventional autothermal gasification, solar gasification and solar pyrolysis processes are compared in Table 4. $U$ values greater than 1 for solar gasification/pyrolysis processes, which indicates the successful solar energy storage as chemical form and fuel calorific value upgrading achievement. In addition, the upgrade factor of solar pyrolysis (this study) is higher than that of solar gasification of biomass (1.188 in [7]) and charcoal (1.3 in [49]), which means that more solar energy is stored by solar pyrolysis than by solar gasification. Oppositely, conventional autothermal pyrolysis and gasification upgrade factors are less than 1 , which is due to the burnt part of the feedstock for providing reaction heat. Indeed, conventional autothermal pyrolysis and gasification require the internal combustion with air of some portion of the injected feedstock mass, in order to supply process heat for the endothermic reactions. For example, on a dry basis, $1.6 \pm 0.3 \mathrm{MJ} / \mathrm{kg}$ is necessary to pyrolyze pine wood of LHV $17.9 \mathrm{MJ} / \mathrm{kg}$ near $500{ }^{\circ} \mathrm{C}[50]$. Therefore, at least $9 \mathrm{wt} \%$ of the injected biomass must be burned uniquely to power the reaction, which inherently decreases the biomass valorization. For bituminous coal (LHV $34 \mathrm{MJ} / \mathrm{kg}$ ) $12 \mathrm{MJ} / \mathrm{kg}$ are required for its steam gasification. Thus, at least $35 \mathrm{wt} . \%$ of the coal must be burned for providing the required reactive heat [5].

Note that all the $U$ values presented in Table 4 are the highest values. $U$ depends on the feedstock and operational parameters. Because heat/mass transfer rates, enthalpy changes and reaction kinetics are strongly affected by these differences, which leads to different product and energy distribution. The lab-scale solar pyrolysis demonstration has been accomplished under realistic operational conditions, except for the highest temperature selected to extend tested parameter range for unexplored domains. The results can help for further scaling up of solar pyrolysis technology.

\section{Conclusion}

The directly irradiated solar reactor prototype for biomass pyrolysis was experimentally operated, yielding bio-oil, bio-char and gas whose proportion depends on the temperature. The gas mainly composed of $\mathrm{H}_{2}$ and $\mathrm{CO}$ increases with temperature. The bio-char carbonization degree was accelerated with increasing pyrolysis temperature. There is no obvious effect of temperature on the water content and element concentration of bio-oil. The number of identified tar species increased from about 52 to 71 when the operating temperature increased from 600 to $900{ }^{\circ} \mathrm{C}$. It decreased to 28 at temperature of $2000{ }^{\circ} \mathrm{C}$. The product characterization also indicates the potential of converting biomass via solar pyrolysis into solar fuels (bio-oil, bio-char and gas), with an upgraded calorific value over that of the feedstock by up to 38$53 \%$ depending on the bio-oil composition. It indicates the successful solar energy storage in chemical form.

\section{Acknowledgments}

This work was supported by French "Investments for the future" program managed by the National Agency for Research under contract ANR-10-LABX-22-01 (labex SOLSTICE), and contract number ANR-10-EQPX-49-SOCRATE (Equipex SOCRATE), and by FP7 European project STAGE-STE, grant agreement $\mathrm{N}^{\circ}: 609837$.

\section{References}

[1] IEA, World Energy Outlook 2014: IEA.

[2] Lund H. Renewable energy strategies for sustainable development. Energy 2007;32:912-9.

[3] Ramachandra TV. Solar energy potential assessment using GIS. Energy Edu Sci Technol 2007;18:101-14.

[4] Sawin JL, Sverrisson F, Chawla K, Lins C, Adib R, Hullin M, et al. Renewables 2014. Global status report; 2014.

[5] Piatkowski N, Wieckert C, Weimer AW, Steinfeld A. Solar-driven gasification of carbonaceous feedstock-a review. Energy Environ Sci 2011:4:73-82.

[6] Chueh WC, Falter C, Abbott M, Scipio D, Furler P, Haile SM, Steinfeld A. Highflux solar-driven thermochemical dissociation of $\mathrm{CO}_{2}$ and $\mathrm{H}_{2} \mathrm{O}$ using nonstoichiometric ceria. Science 2010;330:1797-801.

[7] Nzihou A, Flamant G, Stanmore B. Synthetic fuels from biomass using concentrated solar energy - a review. Energy 2012;42:121-31.

[8] Beattie WH, Berjoan R, Coutures J-P. High-temperature solar pyrolysis of coal. Sol Energy 1983;31:137-43.

[9] Hopkin MW, Dejenga C, Antal MJ. The flash pyrolysis of cellulosic materials using concentrated visible light. Sol Energy 1984;32:547-51.

[10] Tabatabaie-Raissi A, Mok WSL, Antal MJ. Cellulose pyrolysis kinetics in a simulated solar environment. Ind Eng Chem Res 1989;28:856-65.

[11] Chan W-CR, Kelbon M, Krieger BB. Modelling and experimental verification of physical and chemical processes during pyrolysis of a large biomass particle. Fuel 1985;64:1505-13.

[12] Gronli MG, Melaaen MC. Mathematical model for wood pyrolysis comparison of experimental measurements with model predictions. Energy Fuels 2000;14:791-800.

[13] Authier O, Ferrer M, Mauviel G, Khalfi A-E, Lédé J. Wood Fast pyrolysis: Comparison of Lagrangian and Eulerian modeling approaches with experimental measurements. Ind Eng Chem Res 2009;48:4796-809.

[14] Pozzobon V, Salvador S, Bézian JJ. Biomass gasification under high solar heat flux: experiments on thermally thick samples. Fuel 2016;174:257-66.

[15] Zeng K, Minh DP, Gauthier D, Weiss-Hortala E, Nzihou A, Flamant G. The effect of temperature and heating rate on char properties obtained from solar pyrolysis of beech wood. Bioresour Technol 2015;182:114-9.

[16] Zeng K, Gauthier D, Li R, Flamant G. Solar pyrolysis of beech wood: effects of pyrolysis parameters on the product distribution and gas product composition. Energy 2015;93:1648-57.

[17] Zeng K, Gauthier D, Lu J, Flamant G. Parametric study and process optimization for solar pyrolysis of beech wood. Energy Convers Manage 2015;106:987-98.

[18] Morales S, Miranda R, Bustos D, Cazares T, Tran H. Solar biomass pyrolysis for the production of bio-fuels and chemical commodities. J Anal Appl Pyrol 2014;109:65-78.

[19] Zeaiter JN, Ahmad M, Rooney D, Samneh B, Shammas E. Design of an automated solar concentrator for the pyrolysis of scrap rubber. Energy Convers Manage 2015;101:118-25.

[20] Grieco E, Baldi G. Analysis and modelling of wood pyrolysis. Chem Eng Sci 2011:66:650-60.

[21] Özbay N, Apaydın-Varol E, Uzun BB, Pütün AE. Characterization of bio-oil obtained from fruit pulp pyrolysis. Energy 2008;33:1233-40.

[22] Moralı U, Şensöz S. Pyrolysis of hornbeam shell (Carpinus betulus L.) in a fixed bed reactor: characterization of bio-oil and bio-char. Fuel 2015:150:672-8.

[23] Yang SI, Wu MS, Wu CY. Application of biomass fast pyrolysis, part I: pyrolysis characteristics and products. Energy 2014;66:162-71. 
[24] Neves D, Thunman H, Matos A, Tarelho L, Gómez-Barea A. Characterization and prediction of biomass pyrolysis products. Prog Energy Combust Sci 2011;37:611-30.

[25] Yan R, Yang H, Chin T, Liang DT, Chen H, Zheng C. Influence of temperature on the distribution of gaseous products from pyrolyzing palm oil wastes. Combust Flame 2005;142:24-32.

[26] Commandré J-M, Lahmidi H, Salvador S, Dupassieux N. Pyrolysis of wood at high temperature: the influence of experimental parameters on gaseous products. Fuel Process Technol 2011;92:837-44.

[27] Ahmed I, Jangsawang W, Gupta AK. Energy recovery from pyrolysis and gasification of mangrove. Appl Energy 2012;91:173-9.

[28] Morf P, Hasler P, Nussbaumer T. Mechanism and kinetics of homogeneous secondary reactions of tar from continuous pyrolysis of wood chips. Fuel 2002;81:843-53.

[29] Becidan M, Skreiberg Ø, Hustad JE. Products distribution and gas release in pyrolysis of thermally thick biomass residues samples. J Anal Appl Pyrol 2007;78:207-13.

[30] López-González D, Fernandez-Lopez M, Valverde JL, Sanchez-Silva L. Pyrolysis of three different types of microalgae: kinetic and evolved gas analysis. Energy 2014;73:33-43.

[31] Chen Y, Yang H, Wang X, Zhang S, Chen H. Biomass-based pyrolytic polygeneration system on cotton stalk pyrolysis: influence of temperature. Bioresour Technol 2012;107:411-8.

[32] Onay O. Influence of pyrolysis temperature and heating rate on the production of bio-oil and char from safflower seed by pyrolysis, using a well-swept fixedbed reactor. Fuel Process Technol 2007;88:523-31.

[33] Nzihou A, Stanmore B, Sharrock P. A review of catalysts for the gasification of biomass char, with some reference to coal. Energy 2013;58:305-17.

[34] Channiwala SA, Parikh PP. A unified correlation for estimating HHV of solid, liquid and gaseous fuels. Fuel 2002;81:1051-63.

[35] Gaur S, Reed TB. An atlas of thermal data for biomass and other fuels. Golden, CO (United States): National Renewable Energy Lab; 1995.

[36] Mullen CA, Boateng AA, Goldberg NM, Lima IM, Laird DA, Hicks KB. Bio-oil and bio-char production from corn cobs and stover by fast pyrolysis. Biomass Bioenergy 2010;34:67-74.

[37] Huber GW, Iborra S, Corma A. Synthesis of transportation fuels from biomass: chemistry, catalysts, and engineering. Chem Rev 2006;106:4044-98.
[38] Demirbas A. The influence of temperature on the yields of compounds existing in bio-oils obtained from biomass samples via pyrolysis. Fuel Process Technol 2007;88:591-7.

[39] Mourant D, Lievens C, Gunawan R, Wang Y, Hu X, Wu L, Syed-Hassan SS, Li CZ. Effects of temperature on the yields and properties of bio-oil from the fast pyrolysis of mallee bark. Fuel 2013;30(108):400-8.

[40] Wolfesberger U, Aigner I, Hofbauer H. Tar content and composition in producer gas of fluidized bed gasification of wood - influence of temperature and pressure. Environ Prog Sustain Energy 2009;28:372-9.

[41] Cypres R. Aromatic hydrocarbons formation during coal pyrolysis. Fuel Process Technol 1987:15:1-15.

[42] Taralas G, Kontominas MG, Kakatsios X. Modeling the thermal destruction of toluene (C7H8) as tar-related species for fuel gas cleanup. Energy Fuels $2003 ; 17: 329-37$.

[43] Ledesma EB, Kalish MA, Nelson PF, Wornat MJ, Mackie JC. Formation and fate of PAH during the pyrolysis and fuel-rich combustion of coal primary tar. Fuel 2000;79:1801-14.

[44] Ledesma EB, Marsh ND, Sandrowitz AK, Wornat MJ. An experimental study on the thermal decomposition of catechol. Proc Combust Inst 2002;29:2299-306.

[45] Fuentes-Cano D, Gómez-Barea A, Nilsson S, Ollero P. The influence of temperature and steam on the yields of tar and light hydrocarbon compounds during devolatilization of dried sewage sludge in fluidized bed. Fuel 2013;108:341-50.

[46] Zhang Y, Kajitani S, Ashizawa M, Oki Y. Tar destruction and coke formation during rapid pyrolysis and gasification of biomass in a drop-tube furnace. Fuel 2010;89:302-9.

[47] Pattiya A, Suttibak S. Production of bio-oil via fast pyrolysis of agricultural residues from cassava plantations in a fluidised-bed reactor with a hot vapour filtration unit. J Anal Appl Pyrol 2012;95:227-35.

[48] Dickerson T, Soria J. Catalytic fast pyrolysis: a review. Energies 2013;6:514-38.

[49] Piatkowski N, Wieckert C, Steinfeld A. Experimental investigation of a packedbed solar reactor for the steam gasification of carbonaceous feedstocks. Fuel Process Technol 2009;90:360-6.

[50] Daugaard DE, Brown RC. Enthalpy for pyrolysis for several types of biomass. Energy Fuels 2003;17:934-9. 